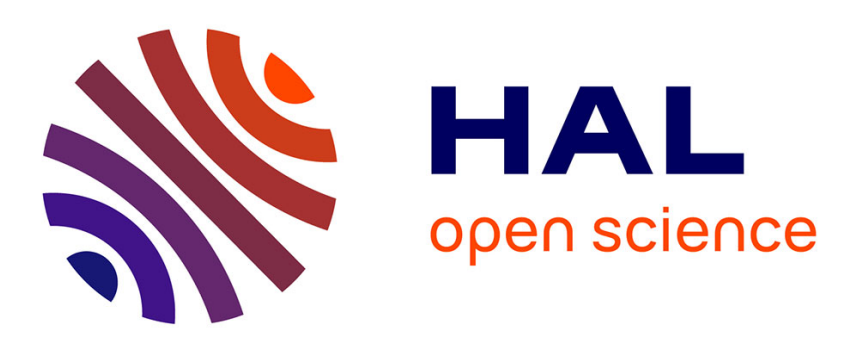

\title{
Non-host facilitators, a new category that unexpectedly favours parasitic weeds
}

\author{
Stéphanie Gibot-Leclerc, Nadia Abdennebi-Abdemessed, Carole Reibel, \\ Nathalie Colbach
}

\section{- To cite this version:}

Stéphanie Gibot-Leclerc, Nadia Abdennebi-Abdemessed, Carole Reibel, Nathalie Colbach. Non-host facilitators, a new category that unexpectedly favours parasitic weeds. Agronomy for Sustainable Development, 2013, 33 (4), pp.787-793. 10.1007/s13593-013-0153-x . hal-01201400

\section{HAL Id: hal-01201400 \\ https://hal.science/hal-01201400}

Submitted on 17 Sep 2015

HAL is a multi-disciplinary open access archive for the deposit and dissemination of scientific research documents, whether they are published or not. The documents may come from teaching and research institutions in France or abroad, or from public or private research centers.
L'archive ouverte pluridisciplinaire HAL, est destinée au dépôt et à la diffusion de documents scientifiques de niveau recherche, publiés ou non, émanant des établissements d'enseignement et de recherche français ou étrangers, des laboratoires publics ou privés. 


\title{
Non-host facilitators, a new category that unexpectedly favours parasitic weeds
}

\author{
Stéphanie Gibot-Leclerc • Nadia Abdennebi-Abdemessed • \\ Carole Reibel $\cdot$ Nathalie Colbach
}

Accepted: 19 April 2013 /Published online: 4 June 2013

(C) INRA and Springer-Verlag France 2013

\begin{abstract}
In Europe, the current decrease of herbicide application increases and diversifies weed flora in crops. As a consequence, there is an increase in the number of pests that use weeds to spread. This change is a major threat to crop production. For instance broomrape-Phelipanche ramosais an obligate parasite of dicotyledonous species that reduces crop yield by up to $80 \%$ of oilseed rape in France. In highly infected fields, broomrape can in turn infect various weed species and thus persist and even proliferate in the absence of host crops. Up to now, three categories of interactions between broomrape and plant species have been identified in monospecific stands: host, non-host and false host. In multispecific stands, broomrape germination and attachment have never been studied despite the use of multispecific crop associations to protect host crops with non-host species in tropical conditions. Therefore, we studied parasite germination and attachment of monospecific vs. multispecific stands, associating broomrape with host plants (oilseed rape), non-host plants (field bindweed) or a combination of both. Experiments were conducted in vitro for 6 weeks and in pots for 3 months. We measured the percentage of germinated broomrape seeds in the
\end{abstract}

S. Gibot-Leclerc · C. Reibel

AgroSup Dijon, UMR1347 Agroécologie, BP 86510,

21000 Dijon, France

N. Abdennebi-Abdemessed $\cdot$ N. Colbach

INRA, UMR1347 Agroécologie,

F-21000 Dijon, France

N. Colbach

e-mail: Nathalie.Colbach@dijon.inra.fr

S. Gibot-Leclerc $(\square)$

Département Agronomie Agroéquipement Elevage

Environnement, AgroSup Dijon, UMR 1347 Agroécologie,

26 Bd Dr Petitjean-BP 87999,

21079 Dijon Cedex, France

e-mail: stephanie.gibot-leclerc@dijon.inra.fr presence of field bindweed or oilseed rape. We analysed the attachment of the parasite on its host. Results unexpectedly show a nearly threefold increase in the infection of host oilseed rape in the presence of field bindweed. We thus proposed a new plant species category called 'non-host facilitator' and a new parasitic interaction process named 'facilitation'. The underlying mechanism is still unknown though we observed that field bindweed was able to support secondary parasite attachments originating from primary attachments on a nearby oilseed rape root system. Our discovery implies the rethinking of parasite management in arable crops, particularly the rotation or association of host with non-host crops, since the non-host crops could actually be non-host facilitators.

Keywords Phelipancheramosa (L.) Pomel · Brassica napus L. C Convolvulus arvensis L. · Parasitism · Weeds · Host plant $\cdot$ Non-host facilitator $\cdot$ Facilitation

\section{Introduction}

In Europe, the current decrease in herbicide use may increase and diversify weed flora in crops, together with a series of companion bioagressors spreading via weeds (Barzman and Dachbrodt-Saaydeh 2011; Melander et al. 2013; Meynard et al. 2003; Parker and Riches 1993; Press and Graves 1995). Among crop bioagressors, Phelipanche and Orobanche genera are obligate parasites of dicotyledonous roots causing severe damage to numerous economically important crops throughout the world, especially in the Mediterranean area (Parker 2009; Rubiales et al. 2009). Broomrape-Phelipanche ramosa (L.) Pomel (syn. Orobanche ramosa) (Joel 2009) — is the most devastating species and has by far the widest range of hosts such as Solanaceae, Brassicaceae and legumes (Joel et al. 2007; Parker 2009; Parker and Riches 1993). In France, 
broomrape (Fig. 1a) can reduce crop yield by up to $80 \%$ in its favourite crop, i.e. oilseed rape (Brassica napus L., Fig. 1b), but also in hemp and tobacco (Brault et al. 2007; Gibot-Leclerc et al. 2003, 2012, 2013). To date, no herbicide has been authorized for controlling broomrape in crops. Several strategies have been developed to control broomrape, including false hosts and catch crops which stimulate germination of broomrape without being infected themselves and use of resistant or tolerant varieties, but none are fully successful (Parker 2009; Parker and Riches 1993; Rubiales et al. 2009). In fields strongly infected by broomrape, the parasite can infect numerous weed species and thus persist and even proliferate in the absence of host crops (Boulet et al. 2001, 2007; Gibot-Leclerc et al. 2003). The ability of various weed species to stimulate and attach parasite germinations has already been demonstrated in controlled conditions for individual species (Boulet et al. 2001, 2007; Gibot-Leclerc et al. 2003).

To date, three distinct types of interactions between broomrape and plant species have been identified in monospecific stands (Joel 2000; Parker and Riches 1993; Press and Graves 1995): (1) host plants stimulate parasite seed

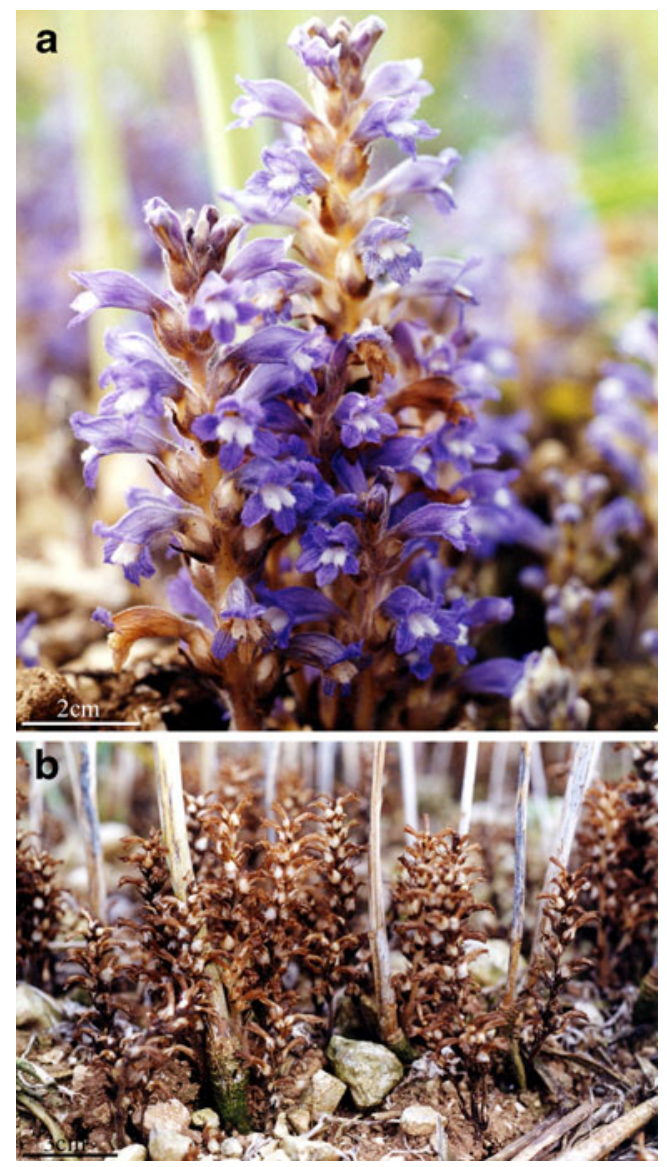

Fig. 1 P. ramosa (broomrape). a Broomrape floral scape, $\mathbf{b}$ high broomrape density in a severely infected oilseed rape plot (Gibot-Leclerc et al. 2012) germination and support subsequent parasite attachment up to seed production; (2) false-host plants stimulate parasite seed germination without attachment and (3) non-host plants neither stimulate parasite germination nor support attachment. But broomrape germination and attachment in multispecific stands have never been studied, though multispecific crop associations are being used in tropical conditions to protect potential host crops through the beneficial effect of non-host species (Hearne 2009; Khan et al. 2000; Kuchinda et al. 2003). Consequently, the objective of the present paper was to compare these two parasite stages in monospecific vs. multispecific stands. In vitro and pot experiments were carried out, associating broomrape with host plants, non-host plants or a combination of both. Oilseed rape was chosen as a host species because it is the most frequent and sensitive host of broomrape (GibotLeclerc et al. 2003, 2012); the chosen non-host species was field bindweed (Convolvulus arvensis L.) because this weed is frequent in oilseed rape (Fried and Reboud 2007) and is considered a non-host species to broomrape (Boulet et al. 2001, 2007).

\section{Materials and methods}

\subsection{Seed origin}

Parasite seeds were collected from natural populations of broomrape (B-oilseed rape pathovar, Brault et al. 2007) that had severely infected fields of oilseed rape in Saint-Jeand'Angély ( $45^{\circ} 56^{\prime} 39^{\prime \prime} \mathrm{N}, 00^{\circ} 31^{\prime} 16^{\prime \prime} \mathrm{W}$; Charente-Maritime, France) in 2001. Once harvested, the seeds were sifted to clean them. Oilseed rape seeds (Lignée Aviso) were har-

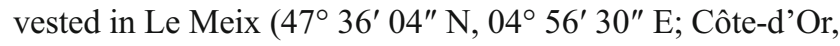
France) in 2007. Field bindweed seeds were bought from Herbiseed in 2010. After collection, all seeds were kept in watertight glass containers at room temperature (approximately $20^{\circ} \mathrm{C}$ ) until the beginning of the experiments.

\subsection{In vitro experiment}

The method was developed and explained in detail by Gibot-Leclerc et al. (2012). Either host (oilseed rape) or non-host (field bindweed) seedlings were put into plastic boxes with broomrape seeds set on paper discs. The development of the parasite on field bindweed or oilseed rape roots was assessed after 6 weeks under a stereomicroscope. The percentage of germinated broomrape seeds in the presence of field bindweed (or oilseed rape) was counted, and the early developmental stages of the parasite on its host were recorded.

The experiment consisted of two plastic boxes, each with five paper discs; one box contained three field bindweed 
seedlings, the other three oilseed rape seedlings. It was repeated four times, in exactly the same experimental conditions starting on April 6, 2010; April 26, 2010; May 17, 2010; and June 7, 2010, respectively. In total, four boxes were thus prepared per plant species (either field bindweed or oilseed rape), each containing three plants and five paper discs with 15-25 parasite seeds per disc, resulting in a total of 60 parasite discs and approximately 1,200 parasite seeds per plant species.

\subsection{Pot experiments}

The method was developed and explained in detail by GibotLeclerc et al. (2013). Field bindweed and oilseed rape seeds were sown into pots as follows: 25 pots with two plants of field bindweed per pot, 25 pots with two plants of oilseed rape per pot, and 25 pots with one plant of field bindweed and one plant of oilseed rape per pot. The 75 pots were placed on a completely randomised design in a growth chamber, with the same growth conditions as in the in vitro experiment. Approximately $50 \mathrm{ml}$ of tap water was added daily. Broomrape development on field bindweed and oilseed rape was assessed 3 months later. The root systems of field bindweed and oilseed rape were taken out of the pots. After washing with tap water, root systems were observed under a stereomicroscope to detect the presence of broomrape. The parasite was described by counting the numbers of individuals having reached the following ontogenic stages according to Gibot-Leclerc et al. (2012): (a) seed germination and contact with host root, (b) attachment on host root, (c) young tubercle, (d) old tubercle, (e) bud, (f) underground stem, (g) stem emergence, (h) flowering and (i) fructification.

\subsection{Statistics}

The effect of the host species on the germination rate of parasite seeds in the in vitro experiment was analysed with a generalized linear model, using PROC GENMOD of SAS with a binomial distribution and taking account for overdispersion with a dispersion parameter estimated by Pearson's chi-square statistic divided by its degrees of freedom:

$$
\begin{aligned}
g(\text { germinated seeds } / \text { total seeds })= & \text { constant } \\
& + \text { host species effect } \\
& + \text { repetition effect } \\
& +\alpha \cdot \text { total seeds }
\end{aligned}
$$

where

$$
g(y)=\log _{n}\left(\frac{y}{1-y}\right)
$$

The effect of the host species and the host association in the pot experiment was evaluated with an analysis of variance, using PROC GLM of SAS:

$$
\begin{aligned}
\text { parasite variable }= & \text { constant } \\
& + \text { host species effect } \\
& + \text { host association effect } \\
& + \text { species } \times \text { association interaction } \\
& + \text { error }
\end{aligned}
$$

The analysed parasite variables were the number of germinated seeds, the number of fixed shoots and the mean growth stage of the fixed shoots. The latter was calculated as follows:

mean growth stage $=\frac{\sum_{i}(\mathbf{i} \cdot \text { number of shoots at stage } i)}{\text { total number of shoots }}$

with $i=1$ to 8 for shoots at attachment, young tubercle, old tubercle, bud, underground stem, stem emergence, flowering and fructification, respectively.

\section{Results and discussion}

3.1 Validation of the oilseed rape host and field bindweed non-host status of broomrape

The in vitro experiment showed that broomrape germination was significantly higher in the presence of oilseed rape seedlings (germination rate $=0.54$, confidence interval $[0.475$, 0.603], Tables 1 and 2) than when next to field bindweed seedlings (chi-square $=440, p<0.0001$ ); in the latter case, germination rate was negligible $(0.008[0.004,0.016])$. The monospecific pots in the second experiment confirmed these findings, i.e. oilseed rape stimulated considerably more parasite germination than field bindweed, and the germination stimulated by the latter was negligible (Fig. 2a). Moreover, this experiment showed that in monospecific stands, the parasite never attached to field bindweed roots whereas it successfully attached to oilseed rape where it usually exceeded the bud stage at the end of the experiment (Fig. 2b).

Our experiments thus confirmed the oilseed rape host and field bindweed non-host status of broomrape that have been extensively reported in the literature (Boulet et al. 2001, 2007; Gibot-Leclerc et al. 2003, 2012). However, the reason why field bindweed is a non-host remains unknown as our experiments were not conceived to establish whether parasite germinations were inhibited by a quantitative or qualitative deficit in root exudates that are necessary to trigger parasite germination (Bouwmeester et al. 2003; Humphrey et al. 2006; Cardoso et al. 2011) or by field bindweed synthesising and excreting parasitic-seed germination 
Table 1 Effect of host species on the germination rate of broomrape seeds in the in vitro experiment. Results of generalized linear model with a binomial distribution and a dispersion parameter

a. Likelihood ratio statistics for type 3 analysis

$\begin{array}{lrrr}\text { Explanatory variable } & D F & \text { Chi-square } & \text { Probability }>\text { chi-square } \\ \text { Host species effect } & 1 & 440.78 & <0.0001 \\ \text { Repetition } & 3 & 127.81 & <0.0001 \\ \text { Total broomrape seeds } & 1 & 2.49 & 0.1143\end{array}$

b. Effect of host species on the mean estimated broomrape germination rates

Host species

Broomrape germination rate

Mean

Confidence limits

$\begin{array}{lllll}\text { Field bindweed } & 0.008 & 0.004 & 0.016 & \\ \text { Oilseed rape } & 0.540 & 0.475 & 0.603 & \mathrm{a}\end{array}$

c. Effect of the experiment onset date on the mean estimated broomrape germination rates averaged over host species

Onset date

Broomrape germination rate

Mean

Confidence limits

$\begin{array}{lllll}\text { 6 April 2010 } & 0.034 & 0.017 & 0.067 & \\ \text { 26 April 2010 } & 0.014 & 0.007 & 0.026 & \\ \text { 17 May 2010 } & 0.358 & 0.250 & 0.483 & \\ \text { 7 June 2010 } & 0.252 & 0.176 & 0.347 & \mathrm{c}\end{array}$

The analysed model was $g$ (germinated seeds/total seeds $)=\mu+$ host species effect + repetition effect $+\alpha \cdot$ total seeds with $g(y)=\log _{n}(y /(1-y))$. Means of a given experimental factors followed by the same letter are not significantly different at $p=0.05$.

inhibitors and/or phytoalexins or coumarins (Serghini et al. 2001; Pérez de Luque et al. 2008).

\subsection{Discovery of plant facilitators}

Associating different host species significantly increased germination rates (Fig. 2a): germination next to field bindweed roots was significantly different from zero only when oilseed rape was also present in the pot. Unexpectedly, associating the germination-triggering oilseed rape with the non-triggering species field bindweed significantly increased parasite germination next to oilseed rape roots and multiplied it by nearly three. The parasite germination surplus also translated into increased infection in multispecific vs. monospecific stands (Fig. 2a). Broomrape was only able to infect field bindweed in the presence of oilseed rape, and again, the infection of host oilseed rape was unexpectedly multiplied by almost three in the presence of field bindweed.

This major result makes it necessary to rethink the current species classification with regard to their susceptibility to root parasites. So far, three distinct types of interactions

Table 2 Effect of host species and host association on the germination of broomrape seeds as well as on the attachment and growth of the resulting parasite shoots

a. Variability in parasite variables explained by host species and species mixture. Partial $R^{2}$ of analysis of variance

$\begin{array}{lcll}\text { Explanatory variable } & \text { Number of germinated seeds } & \text { Number of attached shoots } & \text { Growth stage of attached shoots } \\ \text { Host species } & 0.44 & 0.45 & 0.63 \\ \text { Species mixture } & 0.18 & 0.19 & 0.02 \\ \text { Interaction } & 0.07 & 0.06 & 0.00 \\ \text { All } & 0.68 & 0.70 & 0.66\end{array}$

b. Comparison of means

\begin{tabular}{|c|c|c|c|c|c|c|c|c|c|}
\hline \multirow{2}{*}{$\begin{array}{l}\text { Host species } \\
\text { Oilseed rape }\end{array}$} & \multirow{2}{*}{$\begin{array}{l}\text { Host species association } \\
\text { Alone }\end{array}$} & \multicolumn{3}{|c|}{ Number of germinated seeds } & \multicolumn{3}{|c|}{ Number of attached shoots } & \multicolumn{2}{|c|}{ Mean growth stage } \\
\hline & & 13.76 & & $\mathrm{~b}$ & 13.76 & & $\mathrm{~b}$ & 3.4 & $\mathrm{~b}$ \\
\hline \multirow{3}{*}{ Field bindweed } & With field bindweed & 34.8 & & $\mathrm{a}$ & 34.8 & & $\mathrm{a}$ & 3.2 & $\mathrm{c}$ \\
\hline & Alone & 1.1 & ns & $\mathrm{d}$ & 0 & ns & $\mathrm{d}$ & & \\
\hline & With oilseed rape & 6.16 & & $\mathrm{c}$ & 6.16 & & $\mathrm{c}$ & 4.2 & $\mathrm{a}$ \\
\hline
\end{tabular}

The analysis of variance model was parasite variable $=$ constant + host species effect + host association effect + species $\times$ association interaction + error. Means of a given column followed by the same letter are not significantly different at alpha $=0.05$ (least significant difference test)

${ }^{\text {a }}$ Stages 1 to 8 are attachment, young tubercle, old tubercle, bud, underground stem, stem emergence, flowering and fructification, respectively. 
Fig. 2 Effect of host species and host association on the germination of broomrape seeds as well as on the attachment and growth of the resulting parasite shoots. Least square means and standard errors from analyses of variance model of parasite variable $=$ constant + host species effect + host association effect + species $\times$ association interaction + error. Bars headed by the same letter are not significantly different at alpha $=0.05$ (least significant difference test). a Germination and attachment success, $\mathbf{b}$ average growth stage of attached shoots at the end of the experiment a

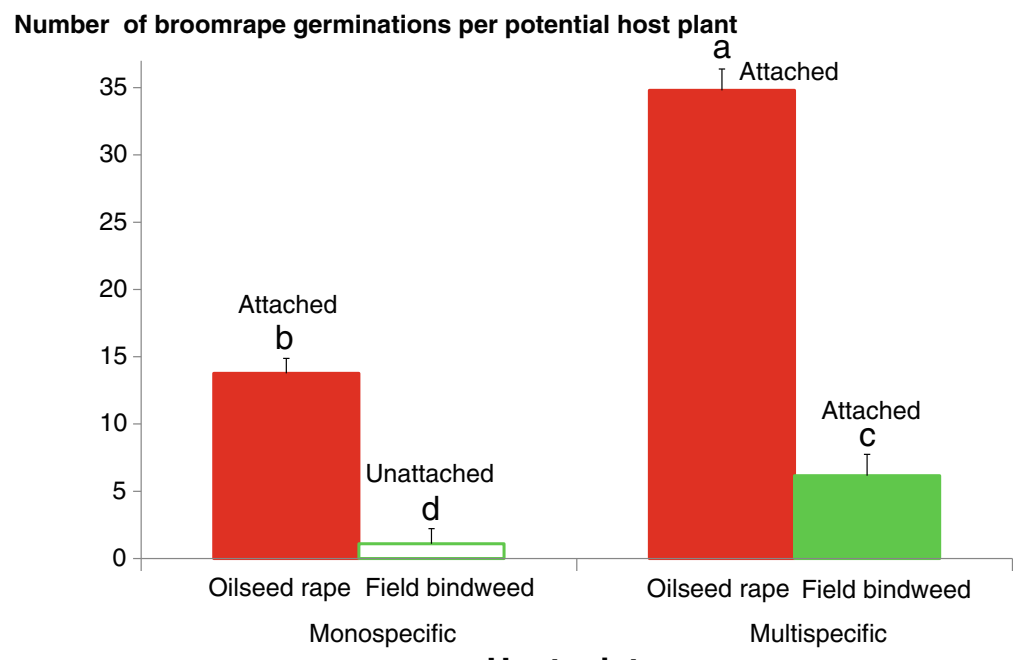

Host mixture

b

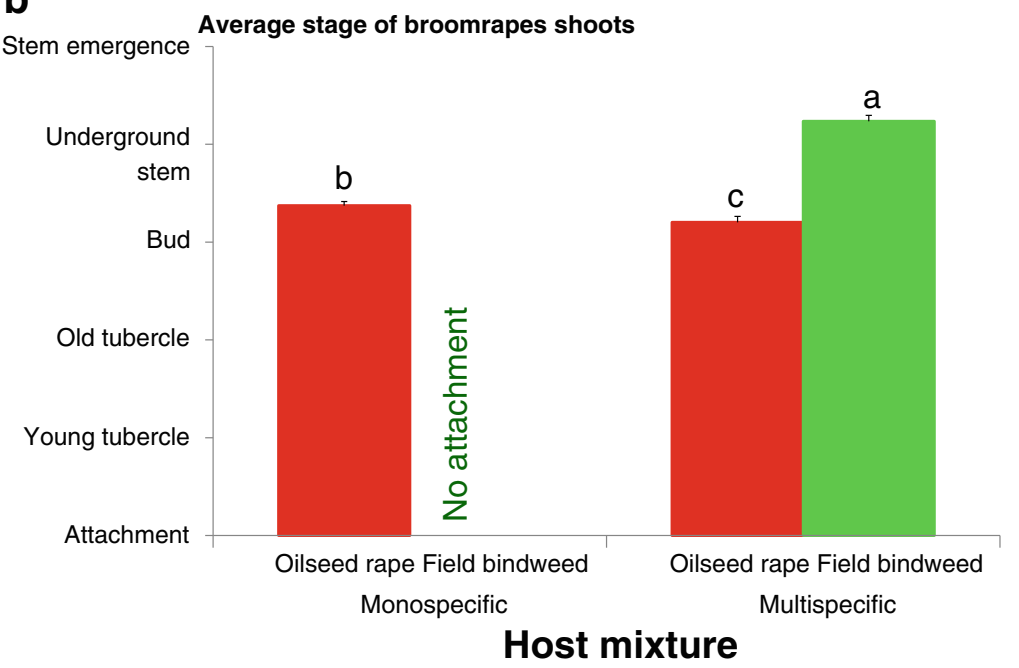

between broomrape and plant species are known: host, nonhost and false host (Joel 2000; Parker and Riches 1993; Press and Graves 1995). We now propose a new species category, i.e. non-host facilitator, and a new parasitic interaction process, i.e. facilitation, in which the infection of oilseed rape (host) by broomrape increases when field bindweed (non-host) is located nearby. Our experiment was unable to identify the causes of the facilitation process as no root exudates were monitored. Moreover, no explanation was found in the literature.

This demonstration makes it necessary to rethink parasite management in arable crops. Crop rotation with non-host crops is a general recommendation for farmers, but our results indicate that this strategy is possibly much less effective than assumed. Some of the non-host crops may actually be non-host facilitators just as a weed species identified as a non-host may increase the infection of crop hosts through facilitation. This risk could also exist in crop associations. Until now, the facilitation process has never been observed in the field. The opposite effect, i.e. a

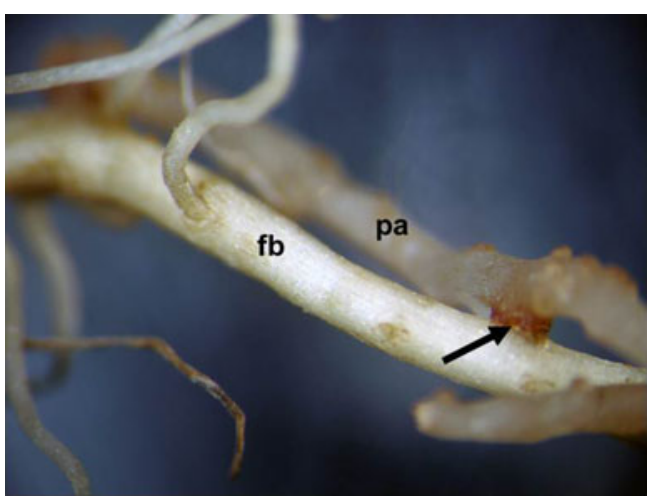

Fig. 3 External view of secondary broomrape attachment (arrow) on a non-host species (field bindweed, $f b$ ) root system after a primary attachment ( $p a$ ) on a host species (oilseed rape) root system in broomrape/field bindweed/oilseed rape pathosystem pot cocultivation. Magnification, $\times 33$ 
decrease in parasitic infections in multispecific canopies, has nonetheless already been reported. Thus, legume intercropping with cereals has been reported to be efficient to cope with Orobanche crenata (Fernandez-Aparicio et al. 2007). Moreover, in Germany, the weedy parts of otherwise heavily infected tobacco fields were observed to be free of P. ramosa, an effect attributed to germination-inhibiting root exudates (Höniges et al. 2009).

The new facilitation process demonstrated here and the interspecific germination-inhibiting effect reported in the literature make it necessary to evaluate both crop and weed species for their ability to trigger and/or attach the parasite, and these both in monospecific and multispecific stands. Moreover, since parasite seeds can survive in the soil for several years (Dhanapal et al. 1996; Rubiales and Fernandez-Aparicio 2012), parasite control cannot be simply reasoned at the annual scale but must be optimized at the multiannual scale. Because of this long-term effect and the multiplicity of the cultural techniques that potentially influence parasite dynamics, either directly or via weeds, developing models that quantify the effect of cropping systems on parasite dynamics in interaction with non-parasite weeds becomes crucial. This was attempted in a preliminary work (PHERASYS, Colbach et al. 2011), but the knowledge of many parasite life stages (soil-borne processes occurring outside host plants, influence of trophic host/parasite relationships on the key stages of the parasite life cycle and host growth) and of weed susceptibility to the parasite is still insufficient.

\subsection{Secondary attachments}

Our results also show an external view of secondary parasite attachments on field bindweed from broomrape established on nearby oilseed rape (Fig. 3, arrow). Such secondary attachments have already been reported on host species (Joel 2000; Joel et al. 2007). In these cases, broomrape first attached on a host root, then penetrated into host tissues and developed a primary haustorium. When the old tubercle stage was reached, the proliferation of cells located around the caulinary meristem led to the formation of a wreath of lateral adventitious roots. These roots were then able to make contact with another host species and produced secondary haustoria attached perpendicularly to the surface of the root of the second species.

Our results show that once attached to a preferred host (here oilseed rape), the parasite is also able to parasitize other nearby species that do not support a primary attachment (here field bindweed). The parasite shoots observed here on field bindweed were fully functional insofar as they were able to grow and develop, even progressing further - in terms of developmental stagethan shoots attached to oilseed rape (Fig. 2b). However, our experiment was not designed to demonstrate whether the parasite actually drew its nutrients from the secondary field bindweed host or from the initial oilseed rape host. Thus, we now need to conduct experiments to confirm that secondary haustoria between field bindweed and broomrape are fully functional in terms of anatomy, e.g. by determining if phloem-mobile dyes move between field bindweed and the parasite.

\section{Conclusion}

The present work was the first to study broomrape germination and attachment in monospecific vs. multispecific stands using in vitro and pot experiments and resulted in the first demonstration of a new parasitic interaction process, i.e. facilitation. Furthermore, the identification of the new 'non-host facilitator' species category makes it necessary to rethink parasite management in arable crops, particularly the rotation or association of host with non-host crops as the latter could actually be non-host facilitators. Consequently, future work is necessary to demonstrate our results in field conditions.

Acknowledgments The present work was financed by INRA, ANR OGM VIGIWEED (ANR-07-POGM-003-01) and Regional Action Plan for Innovation (PARI 2010-9201AAO050S01397). The authors are grateful to Fabrice Dessaint for his explanations on the general linear model.

\section{References}

Barzman MS, Dachbrodt-Saaydeh S (2011) Comparative analysis of pesticide action plans in five European countries. Pest Manag Sci 67:1481-1485

Boulet C, Labrousse P, Arnaud MC, Zehhar N, Fer A (2001) Weed species present various responses to Orobanche ramosa. In: Proceedings of the Seventh International Parasitic Weed Symposium. Faculté des Sciences de Nantes. 228-231. Nantes, France

Boulet C, Pineault D, Benharrat H, Simier P, Delavault P (2007) Adventices du colza et orobanche rameuse. In: AFPP-Vingtième conférence du COLUMA: Journée internationale sur la lutte contre les mauvaises herbes, Fontenay-Le- Compte, France, pp. 326-345

Bouwmeester HJ, Matusova R, Zhongkui S, Beale MH (2003) Secondary metabolite signalling in host-parasitic plant interactions. Curr Opin Plant Biol 6:358-364

Brault M, Betsou F, Jeune B, Tuquet C, Sallé G (2007) Variability of Orobanche ramosa populations in France as revealed by cross infestations and molecular markers. Environ Exp Bot 67:271-280

Cardoso C, Ruyter-Spira C, Bouwmeester HJ (2011) Strigolactones and root infestation by plant-parasitic Striga, Orobanche and Phelipanche spp. Plant Sci 180:414-420

Colbach N, Abdennebi-Abdemessed N, Gibot-Leclerc S (2011) A preliminary approach for modelling the effects of cropping systems on the dynamics of broomrape (Phelipanche ramosa) in interaction with the non-parasitic weed flora. Oléagineux, Corps Gras, Lipides 18:39-45 
Dhanapal GN, Struik PC, Udayakumar M, Timmermans PCJM (1996) Management of broomrape (Orobanche spp.) - a review. J Agro Crop Sci 176:335-359

Fernandez-Aparicio M, Sillero JC, Rubiales D (2007) Intercropping with cereals reduce infection by Orobanche crenata in legumes. Crop Prot 26:1166-1172

Fried G, Reboud X (2007) Evolution de la composition des communautés adventices des cultures de colza sous l'influence des systèmes de culture. Oléagineux Corps Gras Lipides 14:130-138

Gibot-Leclerc S, Brault M, Pinochet X, Sallé G (2003) Potential role of winter rape weeds in the extension of broomrape in PoitouCharentes. C R Biol 326:645-658

Gibot-Leclerc S, Sallé G, Reboud X, Moreau D (2012) What are the traits to Phelipanche ramosa (L.) Pomel that contribute to the success of its biological cycle on its host Brassica napus L. ? Flora 207:512-521

Gibot-Leclerc S, Reibel C, Dessaint F, Le Corre V (2013) Phelipanche ramosa (L.) Pomel populations differ in life-history and infection response to hosts. Flora. doi:10.1016/j.flora.2013.03.007

Hearne SJ (2009) Control-the Striga conundrum. Pest Manag Sci 65:603-614

Höniges A, Hadacek F, Ardelan A, Wegmann K (2009) Allelopathic relations in the rhizosphere between broomrapes and ordinary weeds. In: European Weed Research Society, 2nd International Conference (September 7-10, Santorini, Greece,)

Humphrey AJ, Galster AM, Beale MH (2006) Strigolactones in chemical ecology: waste products or vital allelochemicals? Nat Prod Rep 23:592-614

Joel DM (2000) The long-term approach to parasitic weeds control: manipulation of specific developmental mechanisms of the parasite. Crop Prot 19:753-758

Joel DM (2009) The new nomenclature of Orobanche and Phelipanche. Weed Res 49:1-6
Joel DM, Hershenhorn Y, Eizenberg H (2007) Biology and management of weedy root parasites. Hort Rev (Am Soc Hortic Sci) 38:267-349

Khan ZR, Pickett JA, van den Berg J et al (2000) Exploiting chemical ecology and species diversity: stem borer and striga control for maize and sorghum in Africa. Pest Manag Sci 56:957-962

Kuchinda NC, Kureh I, Tarfa BD, Shinggu C, Omolehin R (2003) Onfarm evaluation of improved maize varieties intercropped with some legumes in the control of Striga in the Northern Guinea. Crop Prot 22:533-538

Melander B, Munier-Jolain N, Charles R et al (2013) European perspectives on the adoption of nonchemical weed management in reducedtillage systems for arable crops. Weed Technol 27:231-240

Meynard JM, Doret T, Luca P (2003) Agronomic approach: cropping systems and plant diseases. C R Biol 326:37-46

Parker C (2009) Observations on the current status of Orobanche and Striga problems worldwide. Pest Manag Sci 65:453-459

Parker C, Riches CR (1993) Parasitic weeds of the world: biology and control. CAB International, Wallingford

Pérez de Luque A, Moreno MT, Rubiales D (2008) Host plant resistance against broomrapes (Orobanche spp.): defence reactions and mechanisms of resistance. Ann App Biol 152:131-141

Press MC, Graves JD (1995) Parasitic plants. Chapman and Hall, London

Rubiales D, Fernandez-Aparicio M (2012) Innovations in parasitic weeds management in legume crops. A review. Agron Sustain Dev 32:433-449

Rubiales D, Fernandez-Aparicio M, Wegmann JDM (2009) Revisiting strategies for reducing the seedbank of Orobanche and Phelipanche spp. Weed Res 49:23-33

Serghini K, Perez De Luque A, Castejon-Munoz M et al (2001) Sunflower (Helianthus annuus L.) response to broomrape (Orobanche cernua Loefl.) parasitism: induced synthesis and excretion of 7-hydroxylated simple coumarins. J Exp Bot 52:2227-2234 